\title{
Peningkatan Usaha dan Inovasi pada Industri Kecil dan Menengah (IKM) Produk Mekaya Losarang Kabupaten Indramayu
}

\author{
Agus Yudianto, Meddy Nurpratama \\ Universitas Wiralodra, Indramayu \\ agus.yudianto@unwir.ac.id, meddynurpratamafe@unwir.ac.id
}

\begin{abstract}
Abstrak
Manajemen inovasi merupakan alat yang digunakan oleh manajer maupun organisasi atau perusahaan untuk mengembangkan produk dan inovasi organisasi atau dengan kata lain manajemen inovasi adalah pengelolaan dan pengorganisasian sebuah proses. Melalui pengabdian masyarakat dan pengembangan, perusahaan melakukan respons terhadap kesempatan eksternal atau internal dan menggunakan upaya kreatif untuk memperkenalkan ide-ide baru, proses atau produk. Untuk menunjang proses pemasaran produk sambal ikan lele pada Industri Kecil dan Menengah (IKM) Mekaya, tim menggunakan metode teknologi digital marketing atau pemasaran online dengan menggunakan media sosial seperti Facebook, WhatsApp, Instagram, dan sebagainya. Selain menggunakan media online tim juga menggunakan media offline dengan melakukan dan mengikuti acara festival dan pameran agar produk sambal ikan lele tersebut banyak diketahui dan dikenal oleh masyarakat. Metode teknologi digital marketing yang akan diimplementasikan untuk proses pemasaran produk sambal ikan lele menggunakan metode partisipatif. Program kegiatan yang dilaksanakan di Industri Kecil dan Menengah (IKM) Mekaya dengan membantu dalam proses pemasaran produk sambal ikan lele (SALE) melalui media sosial dan pemasaran door to door mendapatkan hasil yang cukup memuaskan, sehingga produk tersebut sekarang banyak dikenal dan diketahui oleh masyarakat. Selain membantu dalam pemasaran online, tim juga berhasil melakukan pemasaran offline yaitu dengan mengikuti acara festival atau pameran yang dilaksanakan di Pasar Baru Indramayu selama dua hari. Dengan meningkatnya omset penjualan, yang biasanya proses produksi dilakukan satu bulan sekali, kini proses produksi meningkat menjadi dua kali dalam sebulan. Dengan adanya label pengiriman, produk sambal ikan lele dalam proses pengiriman ke luar kota menjadi lebih teratur dan rapi. Hal ini karena produk kini memiliki identitas tersendiri sebagai pembeda dari produk pesaing. Hal itu juga merupakan salah satu cara untuk menarik minat konsumen karena produk dapat dikemas dengan baik.
\end{abstract}

Kata Kunci: peningkatan usaha, inovasi

\section{Business Improvement and Innovation in Small and Medium Industries Mekaya's Products, Losarang, Indramayu}

\begin{abstract}
Innovation management is a tool used by managers and organizations or companies to develop products and organizational innovations or in other words innovation management is the management and organization of a process. Through community service and development, the company responds to external or internal opportunities and uses creative efforts to introduce new ideas, processes or products. To support the marketing process for catfish sauce products in the Mekaya, the team uses digital marketing technology methods or online marketing using social media such as Facebook, WhatsApp, Instagram, and so on. In addition to using online media, the team also uses offline media by conducting and participating in festivals and exhibitions so that the catfish sauce product is widely known and known by the public. The digital marketing technology method that will be implemented for the marketing process of catfish sauce products uses a participatory method. The program of activities carried out in the Mekaya by assisting in the marketing process of catfish chili sauce (SALE) products through social media and door to door marketing got quite satisfactory results, so that the product is now widely known and known by the public. In addition to assisting in online marketing, the team also succeeded in doing offline marketing by participating in festivals or exhibitions held at Pasar Baru Indramayu for two days. With the increase in sales turnover, which normally takes place once a month, the production process has now increased to twice a month. With the shipping label, catfish sauce products in the process of shipping out of town become more organized and neat. This is because the product now has its own identity as a differentiator from competing products. It is also a way to attract consumers because the product can be packaged well.
\end{abstract}

Keywords: business improvement, innovation 
Vol. 2, No. 2, July, 2021, pp. $165-170$

e-ISSN: 2722-2004

\section{Business}

Improvement

and

Innovation in

Small and

Medium

Industries

Mekaya's

Products,

Losarang,

Indramayu

Agus Yudianto, M. Nurpratama

\section{PENDAHULUAN}

Industri Kecil dan Menengah (IKM) Mekaya didirikan pada 13 Juli 2020 oleh Jehan Fitri Millania dan Dodi Maulana. Mekaya ini berada di Desa Jumbleng RT 03 RW 03 Kecamatan Losarang Kabupaten Indramayu. Mekaya ini memiliki sebuah logo tersendiri sebagai salah satu bentuk identitas dari usaha-usaha yang lainnya.

Konsep yang sangat utama dan penggunaan teknologi pada konsep pembangunan oleh bangsa bahwa untuk diakui secara luas, terutama oleh bangsabangsa yang telah mencapai kemajuan di tingkat dunia internasional seperti Jerman, negara-negara Eropa, dan Jepang (Prayitno dan Santosa, 1996:176).

Porter (1990: 71) menjelaskan bahwa keunggulan daya saing dalam industri-industri pendukung memberikan keunggulan yang potensial bagi industri-industri dalam suatu wilayah, karena industri pemasok seperti itu memproduksi input yang digunakan secara luas dan penting bagi inovasi dan internasionalisasi.

Industri kecil dan menengah (IKM) terbukti memberikan kontribusi positif yang signifikan terhadap upaya-upaya penanggulangan masalah ekonomi (Wahyuningrum, Sukmawati, \&Kartika,2014). Salah satu IKM yang bergerak di bidang perikanan, mencoba memanfaatkan peluang yang ada dengan membuat sebuah usaha yaitu usaha sambal ikan lele (SALE). Mengapa IKM ini membuat usaha SALE? Hal ini dikarenakan di Kecamatan Losarang mempunyai banyak potensi mulai dari sektor pertanian dan sektor perikanan. Di Losarang juga banyak dijumpai tambak para petani budidaya ikan seperti tambak ikan Lele, Ikan Bandeng, dan lain-lain. Oleh karena itu mereka mendirikan sebuah IKM Mekaya yaitu dengan membuat usaha sambal ikan lele (SALE).

Usaha sambal ikan lele (SALE) ini masih tergolong ke dalam usaha skala kecil karena baru berjalan sekitar satu bulan lebih, Oleh karena itu usaha SALE ini masih belum diketahui atau dikenal oleh masyarakat banyak khususnya di sekitar wilayah Losarang tersebut. Permasalahan yang timbul pada usaha ini adalah bagaimana caranya agar usaha tersebut dapat diketahui dan dikenal oleh masyarakat banyak terutama di luar wilayah kecamatan Losarang.

\section{METODE PELAKSANAAN}

Pelaksanaan Pemberdayaan masyarakat dilakukan pada Industri Kecil dan Menengah (IKM) Mekaya yang memproduksi sambal ikan lele yang bertempat di Desa Jumbleng Blok Jangga Kecamatan Losarang Kabupaten Indramayu. Sedangkan metode observasi dilakukan dengan cara mengamati langsung proses pembuatan sambal ikan lele.

Teknologi untuk menunjang proses pemasaran produk sambal ikan lele pada Industry Kecil dan Menengah Mekaya kami menggunakan metode teknologi digital marketing atau pemasaran online dengan menggunakan media sosial seperti Facebook, WhatsApp, Instagram, dan sebagainya. Selain menggunakan media online kami juga menggunakan media offline dengan melakukan dan mengikuti acara festival dan pameran agar produk sambal ikan lele tersebut banyak diketahui dan dikenal oleh masyarakat.

Metode teknologi digital marketing yang akan di implementasikan untuk proses pemasaran produk sambal ikan lele menggunakan metode partisipatif dalam pelaksanaan kami dapat menguraikan bahwa dalam evaluasi pelaksanaan program yang kami lakukan antara lain: 


\section{Media Sosial}

Dalam pelaksanaan program ini, penggunaan media sosial untuk proses pemasaran produk sambal ikan lele mendapatkan respons yang minim dari pemilik Industri Kecil dan Menengah (IKM) Mekaya, dikarenakan dalam proses pemasaran produk melalui media sosial ini akan sangat sulit dalam menarik minat konsumen apalagi banyak produk pesaing seperti sambal cumi, sambal teri dan produk lainnya.

\section{Inovasi Pembuatan Label Pengiriman}

Dalam pelaksanaan program ini, respons dari pemilik Industri Kecil dan Menengah (IKM) Mekaya sangat menerima hasil pembuatan inovasi baru pada desain label pengiriman. Dikatakan bahwa dengan desain label pengiriman ini maka produk sambal ikan lele memiliki identitas tersendiri pada saat pengiriman produk ke luar kota.

\section{Mengusulkan Untuk Mengikuti Acara Festival atau Pameran}

Dalam pelaksanaan program ini, karena sambal ikan lele masih termasuk ke dalam bisnis skala kecil maka produk sambal ikan lele mengikuti salah satu acara festival atau pameran agar produk tersebut banyak dikenal oleh masyarakat banyak. Dari program ini, respons dari pemilik Industry Kecil dan Menengah (IKM) Mekaya sangat menerima dengan baik, agar bisnis tersebut berjalan dengan lancar.

Prosedur kerja di Industry Kecil dan Menengah (IKM) Mekaya ini sama halnya dengan proses pembuatan sambal ikan lele, di antaranya:

1. Olah ikan lele lalu bersihkan

2. Kemudian ikan lele yang sudah di bersihkan dibagi menjadi 2 bagian, sebagian direbus sekitar kurang lebih 1 jam dan sebagian di potong dadu lalu pisahkan

3. Lalu ikan yang sudah direbus di tiriskan kemudian langsung di blender

4. Goreng semua bumbu yang sudah di siapkan lalu haluskan

5. Panaskan minyak sayur kemudian masukan ikan lele yang sudah diblender goreng setengah matang

6. Kemudian masukan bumbu yang sudah dihaluskan tadi lalu aduk sampai rata

7. Masukan ikan lele yang sudah dipotong dadu

8. Kemudian masukan bumbu penyedap rasa lalu masak sambal ikan lele tersebut hingga matang.

\section{HASIL DAN PEMBAHASAN}

Pelaksanaan kegiatan pengabdian masyarakat yaitu dilakukan pemahaman bagi pelaku usaha kecil dengan materi-materi yang disampaikan. Pengabdian dilakukan tim pengabdian masyarakat yang mempunyai kompetensi keilmuan operasional usaha kecil dan pemasaran. Sedangkan pelatihan yang dilaksanakan pada usaha Mekaya yang telah berkembang di Kabupaten Indramayu. Selain itu juga pembinaan dan pendampingan dilakukan dengan memberikan masukan dan pemecahan seputar permasalahan yang dihadapi dalam pengembangan produk dengan berbagai strategi pemasaran produk untuk meningkatkan produktivitas. Indikator hasil secara umum yang dijadikan tolok ukur keberhasilan program adalah sebagai berikut:

1. Usaha Mekaya mampu menjajaki pasar dengan kepercayaan masyarakat yaitu dengan sudah mempunyai izin usaha 
Vol. 2, No. 2, July, 2021, pp. $165-170$

e-ISSN: 2722-2004

\section{Business}

Improvement

and

Innovation in

Small and

Medium

Industries

Mekaya's

Products,

Losarang,

Indramayu

Agus Yudianto, M. Nurpratama
2. Para pengelola usaha dan pemilik diharapkan dapat meningkat ketrampilan dalam pembuatan sambal ikan lele dan pemasaran, pengetahuan tentang manajemen usaha dan bisnis dan pemasaran.

3. Strategi pemasaran dengan membuat kemasan sambal ikan lele.

Berdasarkan identifikasi kekuatan internal dan lingkungan eksternal pada Industry Kecil dan Menengah (IKM) Mekaya, kekuatan usaha ini dapat terlihat dari harga produk yang lebih terjangkau dari yang lain dan pelayanan memuaskan, rapi dan bersih, sehingga konsumen tidak perlu khawatir untuk membeli. Dengan produk sambal ikan lele dari khas rasa dan aroma sehingga konsumen bisa menikmati produk-produk dari Industry Kecil dan Menengah (IKM) Mekaya. Tidak menggunakan bahan pengawet yang berbahaya. Memproduksi sambal ikan lele yang tidak menggunakan bahan pengawet mampu juga menjadi kekuatan untuk menciptakan produk makanan yang sehat dan tidak berbahaya.

Kelemahan yang ada pada Industry Kecil dan Menengah (IKM) Mekaya yaitu peralatan yang kurang memadai, peralatan yang digunakan masih seadanya dengan menggunakan peralatan tradisional. Sulitnya mencari tenaga kerja yang mempunyai keahlian di bidang ini menjadikan pemilik industri kecil dan menengah Mekaya ini tidak bisa bekerja secara maksimal dan lokasi yang kurang strategis. Lokasi yang kurang strategi mengakibatkan produk ini tidak begitu dikenal oleh konsumen. Peluang usaha sambal ikan lele Mekaya yaitu banyaknya minat konsumen peminta sambal sangat digemari oleh sebagian besar masyarakat, karena poduk pelengkap pada menu hidangan makan, hidangan ini masih jarang ditemui di kabupaten Indramayu. Sehinggas bisa menjadikan sambal ikan lele sebagai alternative sebagai menu pelengkap hidangan. Sambal ikan lele bisa menjadi menu pelengkap sehat yang dapat dinikmati oleh anak-anak sampai orang dewasa karena memiliki kandungan bahan-bahan yang bermanfaat bagi tubuh. Maka yang menjadi fokus adalah pasar sasarannya mencakup semua kalangan masyarakat. Ancaman usaha sambal ikan lele yaitu adanya pedagang produk yang sejenis dengan kualitasnya lebih tinggi. Adanya pedagang lain dengan produk yang sejenis menjadi ancaman yang cukup kuat untuk usaha ini. Kenaikan harga bahan baku yang kurang stabil dapat menjadi ancaman serius bagi pelaku industri kecil dan menengah ini, terutama harga dari cabai dan lele.

Beberapa program yang telah dibuat dan dilaksanakan dengan baik diharapkan dapat memberikan pengaruh positif bagi pemilik industri kecil dan menengah maupun bagi pelaksana pengabdian. Berikut ini pencapaian kegiatan dalam pelaksanaan pengabdian masyarakat yaitu:

1. Pembuatan Surat Izin Usaha Mikro (SIUMK)

Dengan adanya tanda legalitas kepada pelaku usaha dalam bentuk izin usaha mikro. Maka usaha Industry Kecil dan Menengah (IKM) Mekaya ditargetkan punya izin usaha.

2. Pembuatan logo dan stiker produk Industri Kecil dan Menengah (IKM) Mekaya

Pembuatan logo dan stiker bertujuan sebagai tanda pengenal produk Industri Kecil dan menengah (IKM) Mekaya dan sarana promosi yang efektif untuk Industri kecil dan Menengah (IKM) Sambal lele, yang mana di dalamnya terdapat informasi seputar alamat, sosial media, dan contact person yang bisa dihubungi oleh konsumen. 
3. Pembuatan Kemasan produk Industri Kecil dan menengah (IKM) Mekaya yang lebih menarik.

Karena pengemasan sebelumnya masih biasa saja dan kurang menarik maka dibuat kemasan yang lebih menarik dengan desain yang unik dan ditambah stiker logo produk agar dapat lebih dikenal oleh konsumen.

4. Pembuatan pembukuan keuangan sederhana

Penyusunan buku keuangan sederhana dapat mempermudah pemilik Industri Kecil dan Menengah (IKM) Mekaya dalam melakukan kegiatan bertransaksi sehingga mampu mengetahui besar kecilnya pengeluaran dan pemasukan yang diperoleh.

5. Pendaftaran Surat Izin Produksi Rumah Tangga (P-IRT)

Pembuatan P-IRT ini bertujuan untuk sebagai jaminan bagi para konsumen mengenai produk yang ditawarkan oleh pemilik Industri Kecil dan Menengah (IKM). mendaftarkan Industri Kecil dan Menengah (IKM) Mekaya di Dinas Kesehatan di Kabupaten Indramayu mengenai pelatihan penyuluhan.

Dari permasalahan tersebut, terdapat beberapa solusi untuk menyelesaikan masalah yang dihadapi oleh Industri Kecil dan Menengah (IKM) Mekaya di antaranya sebagai berikut.

\section{Pemasaran Online}

Pemasaran online merupakan pemasaran yang dilakukan dengan menerapkan sistem teknologi informasi dan komunikasi di mana produk tersebut ditawarkan melalui media sosial seperti Instagram, WhatsApp, Facebook, YouTube, dan media sosial lainnya. Dengan cara seperti itu pemasaran akan lebih fokus dan efektif, begitu juga produk tersebut akan semakin diketahui dan dikenal oleh masyarakat banyak .

Secara peringkat Facebook masih menjadi sosial media yang paling populer di dunia dengan 2,449 milyar akun. Lagi-lagi angka yang mencengangkan karena separuh dari penggunaan sosial media dunia adalah untuk Facebook. Sementara sisanya dibagi-bagi dengan sosial media lain.

Peringkat kedua ditempati oleh YouTube dengan jumlah akun mencapai 2 milyar akun. Di peringkat tiga adalah Instagram dengan 1 milyar akun. Selanjutnya adalah pendatang baru yang mencengangkan yakni TikTok dengan 800 juta akun.

We Are Social sebenarnya melansir data peringkat sosial media dengan memasukkan aplikasi pesan singkat di dalamnya seperti WhatsApp, FB Messenger, dan WeChat. Sedangkan di Indonesia, media sosial yang paling banyak digunakan adalah YouTube, ini dilihat berdasarkan laporan digital tahun 2020 yang dilansir We Are Social dan Hootsuite.

Dengan mengacu pada penggunaan media sosial terbanyak di Indonesia tahun 2020 maka dengan ini kami berinisiatif untuk memasarkan produk SALE melalui media sosial di antaranya Facebook, WhatsApp, Instagram, dan YouTube agar produk bisa laku di pasaran dan dikenal seluruh masyarakat khususnya di Indramayu dan sekitarnya. Selain itu kami menggunakan metode harga promo dan free ongkir khusus untuk sekitar kecamatan Losarang dengan pembelian minimal 2 pcs.

\section{Pemasaran Door To Door}

Pemasaran door to door merupakan salah satu cara memasarkan sebuah produk di mana kelompok Industri Kecil dan Menengah (IKM) Mekaya akan melakukan komunikasi dan berbincang dengan konsumen secara langsung. Dalam 
Vol. 2, No. 2, July, 2021, pp. $165-170$

e-ISSN: 2722-2004

\section{Business}

Improvement

and

Innovation in

Small and

Medium

Industries

Mekaya's

Products,

Losarang,

Indramayu

Agus Yudianto, M. Nurpratama

teknik pemasaran ini, kita harus lebih memperhatikan tutur bahasa yang akan diucapkan kepada konsumen agar konsumen tersebut merasa puas dengan produk yang ditawarkan. Setelah konsumen merasa puas dengan produk tersebut maka konsumen akan berkomunikasi dengan teman, kerabat dan keluarganya, untuk membeli lagi produk tersebut.

\section{SIMPULAN}

Berdasarkan hasil dari kegiatan Pemberdayaan masyarakat di Industri Kecil dan Menengah (IKM) Mekaya maka pencapaian dari program kegiatan tersebut adalah sebagai berikut: Program kegiatan yang kami laksanakan di Industri Kecil dan Menengah (IKM) Mekaya dengan membantu dalam proses pemasaran produk sambal ikan lele (SALE) melalui media sosial dan pemasaran door to door mendapatkan hasil yang cukup memuaskan, sehingga produk tersebut sekarang banyak dikenal dan diketahui oleh masyarakat. Selain membantu dalam pemasaran online, kami juga berhasil melakukan pemasaran offline yaitu dengan mengikuti acara festival atau pameran yang dilaksanakan di Pasar Baru Indramayu selama dua hari. Dengan meningkatnya omset penjualan yang biasanya melakukan proses produksi satu bulan sekali sekarang proses produksi meningkat menjadi dua kali dalam sebulan. Dengan adanya label pengiriman, produk sambal ikan lele dalam proses pengiriman ke luar kota menjadi lebih teratur dan lebih rapi karena memiliki identitas tersendiri sebagai pembeda dari produk pesaing, dan itu merupakan salah satu cara untuk menarik minat konsumen karena produk dapat dikemas dengan sebaik mungkin Dalam melaksanakan program kegiatan tersebut tentunya kami harus lebih semangat dan lebih keras lagi dalam berusaha untuk mempromosikannya, karena produk sambal ikan lele memiliki produk pesaing yaitu seperti sambal cumi dan sambal teri. Dengan demikian, itu semua merupakan sebagai bahan evaluasi kami untuk terus berinovasi dan berkreativitas dalam melaksanakan kegiatan tersebut agar ke depannya menjadi lebih baik lagi

\section{DAFTAR PUSTAKA}

Christiana Y, Pradhanawati A, \& Hidayat W. (2014). Pengaruh kompetensi wirausaha, pembinaan usaha dan inovasi produk terhadap perkembangan usaha (studi pada usaha kecil dan menengah batik di sentra pesindon kota Pekalongan). Dipenogoro Journal of Social and Politic, 1-10

Dhewanto, W. (2015). Managemen Inovasi-Peluang Sukses Menghadapi Perubahan. Yogyakarta: ANDI.

Porter, M. E. (1990). The Competitive Advantage of Nations. New York: The Free Press A Division of Macmillan, Inc.

Morosini, P. (2004). Industrial Clusters, Knowledge Integration and Performance. World Development 32(2). 305-326.

Wahyuningrum P., Sukmawati A., \& KartikaL(2014). Peningkatan Kinerja Usaha Kecil dan Menengah (UKM) Kluster Kerajinan di Kota Depok Menggunakan The House Model. Jurnal Manajemen dan Organisasi, 5(2). 154-166

Wiyadi. (2009). Pengukuran Indeks Daya Saing Industri Kecil Menengah (IKM) Di Jawa Tengah. Jurnal Siasat Bisnis 13(1). 77-92. 